\title{
A critical interrogation of the prevailing teaching model(s) of English pronunciation at teacher-training college level: A Chilean evidence-based study
}

\author{
Mauricio Véliz Campos*
}

\begin{abstract}
The present qualitative study aims to, from a critical perspective, uncover the beliefs and attitudes that pre-service English teachers have with regard to diverse linguistic phenomena, viz. perceptions about English varieties, implications of a foreign accent in teachers of English, and the spread of English across the world. Similarly, it intends to unveil the factors that contribute to the establishment of such belief systems. The results show that highly stereotypical beliefs prevail with regard to varieties and accents of English, and that knowledge about the spread of English is rather meagre. Also, it becomes apparent that both implicit and explicit discourses used by teacher trainers exert a powerful influence on the construction of belief systems.
\end{abstract}

Key words: varieties of English, (foreign) accent, spread of English.

\section{Un análisis crítico de los modelos predominantes en la enseñanza de la pronunciación del inglés en programas de formación docente: un estudio chileno basado en evidencias}

\section{Resumen}

El presente trabajo corresponde a una investigación cualitativa, enfocada desde una perspectiva crítica, que pretende develar las creencias y actitudes que evidencian estudiantes de un programa de preparación de profesores de inglés en relación a diversos fenómenos lingüísticos; entre ellos se destacan las percepciones sobre las variedades del inglés, implicancias de un acento extranjero en profesores de inglés, la masificación del inglés en el mundo y factores que contribuyen a los sistemas de creencias sobre las temáticas abordadas. Los resultados señalan que prevalecen representaciones estereotipadas sobre variedades del inglés y acentos, y que el nivel de conocimiento sobre masificación del inglés es magro; junto a ello, se evidencia una fuerte influencia de los relatos, tanto explícitos como implícitos, de sus docentes en la construcción de dicho sistema de creencias.

Palabras clave: variedades de inglés, acento (extranjero), masificación del inglés.

* Director de la Escuela de Humanidades y Ciencias de la Universidad Católica Silva Henríquez. mveliz@ucsh.cl 


\subsection{Introduction}

It seems that even though teaching preparation courses often incorporate a call for reflective teaching in their trainees, which takes the form of systematic sessions where thought-provoking scenarios result in practices interrogated and innovative pedagogical treatments, lecturers do not equally interrogate the tenets supporting their own teaching. As a way of illustration, a quick glance at the descriptors of the English teacher preparation courses in Chile reveals that concepts such as critical thinking and reflective teaching recur without respite, which raises questions relating to the depth and breadth of the (recurrent) concepts used: Either all of the programmes are equally of prime excellence, an argument that collides head-on with the mandatory accreditation process that such programmes must undergo in Chile and the ensuing diverse results, or crucial concepts such as those mentioned above are void of true meaning.

One expects that those institutions which train teachers will readily engage in processes that interrogate their tenets first, for (even mainstream) criticality cannot be developed if those who allegedly instil critical thinking and reflective teaching do not seriously go through a critical interrogation of the principles they themselves hold.

One of the various areas which lends itself to critical interrogation, within the framework of English teacher training programmes deals with the models used in the teaching of pronunciation. In Chile -unlike other countries, especially (northern) European- students who enrol in English teacher training programmes do not hold forth in English at the time of commencement of their academic programme, thus the training process entails the concurrent development of linguistic skills and pedagogical competencies.

This investigation is immersed in the Critical Applied Linguistics paradigm (CALx henceforth): it seeks to raise awareness amongst the different participants of the English teacher training process in that it critically interrogates one's own practices, principles and assumptions with regard to the model used in the teaching of English pronunciation. This is, I claim, what perhaps Fairclough (1992) regards as a condition for social change. The investigation is conducted following a qualitative methodology, wherein the a structured interview is employed to collect data from a group of 15 students from a 5-year English teacher training in Santiago-Chile. The interview is aimed at collecting data from students from different years/levels about the following broad issues: accent, 
native speaker, materials used in pronunciation teaching/learning, other Englishes, and the spread of English. An ensuing content analysis follows, using conventional techniques such as memoing, which yield the conclusions contained in section 5.0

\subsection{Literature review}

\subsection{Other Englishes: a fairly long-standing apple of discord}

The spread of English varieties in the world and its increasing acceptance has broken ground in the relevant literature, giving rise, for instance, to the emergence of journals such as World Englishes; books (MacCarthur's (1998) book The English languages); and the widely-used set phrase 'new Englishes'. Such rapid spread results, in part, from the 'demographic change in the users of English', as Ferguson (2006: 149) puts it: the group of L2 users of English greatly outnumbers that of 'native speakers'. Also, the critical interrogation, especially arising from CALx, has yielded new re-definitions of concepts which until recently remained somewhat untouched; some of these concepts are native speaker, native accent, EFL, ESL, amongst others. Undoubtedly, Kachru's (1986) model of sociolinguistic contexts where English is used constitutes a major contribution. He proposes three circles, wherein an inner circle represents countries where English has traditionally been a native language (The UK, The US); an outer circle groups countries where English is mainly used for education purposes and stands as an official language (India, Nigeria, Singapore); and an expanding circle, where we find countries where English has no official status.

Despite the monolithic nature of Kachru's model, for it portrays a rather static status quo in the different circles, it proves useful when attempting to draw a line between the different contexts for English usage.

New Englishes are often thought to relate to post-colonial societies, such as India, Malaysia or Pakistan. In such countries a whole range of varieties can be heard, yet the commonality amongst all these varieties is 'a measure of divergence from British or American English', (Ferguson, 2006: 152), at any (if not all) the linguistic components, viz. phonology, vocabulary, and grammar. It is pointless, at least in this work, to determine whether the new Englishes result from (i) a collective process of macroacquisition on the part of the new speech community, thus 
developing its own variety where divergence should not be treated as errors, or (ii) added individual stages of fossilization which are later disseminated. What really matters is that, as the concern raised in this work suggests, new pronunciation teaching proposals should reflect our current scenario of English in the world, i.e. a more realistic sociolinguistic reality.

The teaching of pronunciation has inevitably entailed subscribing to a variety of English, especially at teacher-training college level. Such decisions must now be made in the broader framework of world Englishes.

The unprecedented spread of English has brought about equally unprecedented scholarly discussions. Such debates have brought together strongly opposing views: in one camp influential and prolific authors such as Sir Randolph Quirk have radically put forth provocative claims about 'the dubious advantages in exposing the learner to a great variety of English usage', (Quirk 1985: 6), while in the other, linguists such as Kachru have critically examined constructs such as native speaker, accent, Englishes, amongst others.

Quirk (1989: 8) points out that there is a need 'for native teacher support and the need for non-native teachers to be in constant touch with the native language'. While he recognises the need for an international language, he leaves no room for other varieties of English other than what he terms 'standard' English. Indubitably, such radical judgements have an impact on language policy and planning, especially in the 'expanding circle', and perhaps to a lesser extent in the 'outer circle'; in such countries, EFL teachers are required to evidence a native(-like) accent, while in the 'inner circle' foreign language teachers are not socially or politically coerced to speak with a native accent. Quirk implicitly accuses Kachru's position as heavily ideological, yet is Quirk's position not ideological at all?

Crystal (1997) apparently sees the spread of English as conceptually linked to progress, while Philipson (2003) sees the dominant position of the English language as partly linked to, for example, the demise of other languages, ever-increasing inequalities and grossly big businesses.

It is interesting to note that Halliday et al. (1964) were some of the first authors who raised questions about the continued use of either British or American models for the teaching of English. Prator (1968), on the other hand, comes across as a radical guardian of intelligibility by suggesting that the international value of the English language can be jeopardised if groups of users hold forth in diverse varieties of the 
language. Prator's concern, as has been demonstrated, has been proven wrong, by and large, due to the power of communications.

Ferguson (ibid.) reports that Smith and Nelson (1985) dissect the construct of intelligibility and provide a breakdown for it by suggesting that it implies three distinct processes:

- Intelligibility: recognition of utterances;

- Comprehensibility: understanding of propositional utterance meaning;

- Interpretability: understanding of speaker's intention.

It must be pointed out that much of the work conducted in the area of intelligibility, especially from a pronunciation perspective centres on the first sub-sense of intelligibility. Besides, the 'native-speaker' is the one who is summoned to pass judgement on degrees of intelligibility, as though our students were bound to engage in communication with native speakers in the main, (Jenkins, 2000).

Levis (2006) suggests a matrix including different communicative contexts where native speakers (NSs) and non-native speakers (NNSs) can be found. The resulting contexts can dictate, in his view, different teaching priorities:

LISTENER

Native speaker SPEAKER

Non-native speaker

\begin{tabular}{|c|c|}
\hline Native speaker & Non-native speaker \\
\hline A. NS-NS & B. NS-NNS \\
\hline C. NNS-NS & D. NNS-NNS \\
\hline
\end{tabular}

Quadrant A: Successful communication -supposedly!

Quadrant B: Average ESL context

Quadrant C: Area of current research on intelligibility. NNSs are viewed as responsible for communication.

Quadrant D: EIL context.

The above matrix does not truly reflect the world's complexity; Kachru's (1986) model containing three circles should be represented in the matrix. To make the matter even worse, it should be borne in mind that Kachru's model needs revisiting in the light of recent geopolitical changes which have reshaped the status of English in a number of countries across the world.

Abercrombie (1949: 120), a most prominent linguist and phonetician, argued that 'language learners need no more than a comfortably intelligible pronunciation'. Several others have made similar claims, 
yet empirical data underpinning such claims is seldom referenced. In conclusion, evidence-based research has much potential to set realistic pedagogical goals: can a 'native' accent be attained at all? What can be attained? Where do we set the yardstick for the levels of pronunciation achievement (especially in an EIL context)? What should lecturers emphasize in their particular settings: segments or suprasegments? Both are teachable, but how much of it (them) is actually learnable?

\subsection{A foreign accent}

In a similar vein, the discussion of varieties of English in the world, together with alleged intrinsic values, and the adoption of one, leaving others out by default, does touch on the native vs. non-native accent model debate. Indeed, Jenkins $(2000,2002)$ argues that English as an International Language (EIL) should not adopt a native model of pronunciation; rather, L2 speakers (and teachers) should adjust their speech to cater for an international scope of English language use, thus elevating the value of mutual intelligibility at the expense of sounding native-like.

Evidencing a 'non-native' accent -however loaded the prefix 'non-' may sound- might have a slightly positive effect: it signals to a NS that modified input is required (Gass and Varonis, 1984); nevertheless, it can certainly have pernicious effects due to lowered levels of intelligibility, such as 'negative social evaluation and discrimination' (Lippi-Green, 1997: 385).

Derwing and Munro (2005) suggest that our understanding of the relationship between accent and pronunciation teaching lacks supporting theoretical evidence. We know very little, for instance, about the effect of foreign accents on communication. Indeed, such impact must be studied from both production and perception in diverse speech communities, viz. inner circle, outer circle, and expanding circle-following Kachru's model.

According to Levis (2005), there are two opposing views with regard to the teaching of pronunciation: nativeness vs. intelligibility; the former seems to have prevailed up until the 60s. Ever since then, when 'science' came into the picture, a cumulative body of knowledge produced in the areas of psycholinguistics and sociolinguistics has provided empirical evidence about the futility of striving to achieve a native accent in our post-puberty students. 
Two types of evidence are usually provided in order to establish a relationship between nativeness and age:

(i) 'Wolf-children' (children who have grown up in isolation and later have been rescued), e.g. Victor and Genie, where the pattern observed is that post-rescue progress in language development is evidenced, but of a limited and abnormal kind.

(ii) Deaf subjects who later acquire sign language. Long (1990) cites a number of studies indicating that such acquisition is characterised by deficits of various kinds, e.g. certain rules of American Sign Language (ASL) are better acquired before the age of six; better results when learned in childhood.

Scovel (1988) claims that those who begin to be exposed to an L2 after the age of 12 cannot 'pass themselves off as native speakers phonologically', which applies to the vast majority of our students (pre-service teachers of English) in Chile and the sample. Despite the ample evidence suggesting that a native accent is indeed virtually impossible to achieve, pronunciation teaching materials, especially at advanced levels, implicitly suggest otherwise. Thus the (wrong) epistemological assumption is that communication can be dramatically impaired when foreign accents are noticeably strong. Indeed, empirical evidence suggests that a remarkably foreign accent and lowered levels of understanding do not necessarily constitute a positive correlation, (Munro and Derwing, 1999). According to the intelligibility principle, a specific pronunciation mistake will yield a specific type of effect on communication. Consequently, on account of the diverse specific values that each possible pronunciation feature may have, some features should be emphasized, while others should be de-emphasised.

Jenkins (2000) proposes a phonological inventory for English as Lingua Franca (ELF henceforth) and distinguishes between essential and non-essential features for international intelligibility, especially for L2 English users, which provides significant indications for pedagogical adjustment in the teaching of English pronunciation.

It must be noted that Jenkins' proposed core arose from a good deal of empirical research conducted in the area of intelligibility, unlike earlier proposals based largely upon impressionistic views: Ogden (1930), Quirk (1981).

Amongst the non-essential features of RP English -also shared with other varieties- are the following: 
1. Dental sounds /t/ and /d/, together with dark 'l';

2. Weak forms;

3. Features of connected speech, e.g. assimilation;

4. Pitch direction, especially signaling attitude or grammatical meaning;

5. Lexical stress;

6. Stress-timed rhythm.

On the other hand, amongst the features that Jenkins includes as part of the ELF core are:

1. The consonant inventory, except for those mentioned above;

2. Aspiration of fortis plosives and variable vowel length;

3. Consonant clusters;

4. Nucleus accent placement, especially in contrastive positions.

\subsection{Pronunciation materials and pronunciation/phonetics lecturers}

It is true to claim that there is ever-growing literature on speech production and perception, especially in the form of prestigious journals such as Journal of the Acoustical Society of America, Journal of Phonetics, and Language and Speech. Nevertheless, Levis (1999: 37) asserts that 'intonational research is almost completely divorced from language teaching'. It needs to be said, however, that the seemingly rapid growth in literature dealing with pronunciation does not compare with the abundant research in grammar and vocabulary. As a way of illustration, The Handbook of Second language Acquisition does not make any reference to pronunciation research; Nunan (1999) devotes 2.5 pages to pronunciation, and treats it purely from a critical period hypothesis viewpoint. Similarly, teacher training materials contain, for the most part, little research information about pronunciation (e.g. Hedge, 2000; Lightbown and Spada, 1999; Willis, 1996).

Also, pronunciation materials are, for the most part, not necessarily designed in the light of relevant research; they are produced without much regard for the multifarious potential users. The situation becomes even more problematic when, as is the case of Chile, the number of English teacher training courses at university level has soared up over the last ten years. A dramatic increase has been observed from nearly 20 programmes scattered throughout the country in the 90s to nearly 100. Such a crude fact raises questions about the overall quality of the ample academic offer, and particularly about the teaching of pronunciation. 
On the pronunciation/phonetics lecturers' level of suitability, Breitkreutz, Derwing, and Rossiter (2002) report that 67\% of ESL teachers in Canada received no training for the teaching of pronunciation. Other studies show that, by and large, teachers do not feel confident enough to teach pronunciation, (MacDonald, 2002). This information also reflects the (still) undocumented and impressionistic view of Chile's pronunciation lecturers.

As far as the materials used to teach pronunciation/phonetics go, it needs to be said that there exist some outright bad quality materials containing either wrong information or teaching techniques void of theoretical underpinnings. For instance, Usher (1995) claims that the distinction between $/ \mathrm{b} /$ and $/ \mathrm{p} /$ lies in that the former is pulmonary ingressive and the latter is pulmonary egressive, which collides with well-established principles in English phonetics. Other authors such as Stuparyk (1996) insist on advising having students hold a pencil between their nose and top lip, with little -if any! - theoretical evidence.

Pronunciation teaching materials continue to heavily rely on minority prestigious accents such as Received Pronunciation (RP) or General American (GA), within a context where newly (still insufficient, though) produced evidence suggests that such accents can be regarded as rather unintelligible, (Deterding, 2005).

\subsection{Paradigm, methodology and method of the investigation}

The present study is immersed in the paradigm called critical applied linguistics (CALx), where one of the key elements is to bring about change. Pennycook (1999: 329) explains, while commenting on the special issue of TESOL Quarterly devoted to CALx, the purposes he views for that particular issue by saying that it aims to 'address both critical ways of teaching English and critical appraisals of contexts in which English is being taught'. One of the themes Pennycook (1999: 331) focuses on deals with 'transformative pedagogy: [in other words] how does the particular approach to education hope to change things'. Likewise, he adds that an 'element of a critical approach to TESOL is the inclusion of a means of transformation', (p. 335). In this respect, and on a more personal level, the first quasi-tangible effect that this study aims to bring about is a permanent reflective and reflexive attitude towards our own professional practices, in conjunction with the corresponding 
underlying assumptions as teacher trainers, pronunciation instructors, and/or phonetics lecturers. This state of reflection, followed by the ensuing critical interrogation of one's own practices, principles and assumptions, is perhaps what Fairclough (1992) regards as a condition for social change.

Unlike interpretivism, where the world is looked upon as a complex and ambiguous entity, wherein multiple realities coexist and the researcher relies on the 'participants' views of the situation being studied', (Cresswell, 2003:8), CALx studies -as is the case in this work- intend to at least provoke the audience and ultimately transform reality.

The methodology used in this work, understood as a strategy to a research design intimating an epistemology and ontology, is more of a 'multiple participant meanings' type, where the complex reality of human experience is unravelled by systematically analysing individual accounts. The terms qualitative and quantitative, on the other hand, refer to the data collection methods, analysis and reporting modes, rather than approaches to research.

The structured interview was preferred for various reasons, yet it is important to point out some preliminary considerations with regard to interviews in general:

(i) The distinction between structured and unstructured interviews (or directive and non-directive, in Richards' terms) is not always a clear-cut one (Richards, 2003);

(ii) Both types of interviews offer their own advantages and disadvantages: the unstructured interview offers more potential for richness of data, yet it generally poses greater difficulty in handling the very same data, while the structured interview offers a greater opportunity to handle the data more easily, yet it minimises the possibility to get in-depth perspectives from the interviewee;

(iii) Although the preferred type of interview was the structured one, an element of unstructuredness was introduced towards the end of the interview by asking the interviewee to elaborate on any of the issues addressed throughout the interview.

As for the reasons that led the researcher to opt for the structured interview, I must point out the following: 
- As stated in 3.1, the interviewer, a senior pre-service teacher, was properly trained for this particular task, for the researcher happens to be one of the phonetics lecturers and the Head of the English teacher training programme, which posed a great potential for bias and thus a potential jeopardy to the validity of the results;

- The interviewer achieved a good rapport with the interviewees, not only because the relationship was more horizontal than if conducted by the researcher himself, but also because he is held in high esteem by his fellow students. Also the fear of evaluation or superiority was considerably minimised;

- The interviewer received training form the researcher in order to properly conduct the interview, viz. relevant reading, piloting questions and ensuing conferencing with the researcher;

- The interviewer did leave some room towards the end of the interview for further elaboration;

- The researcher, an experienced phonetics lecturer, did make use of his prosodic expertise when listening to the recordings for suprasegmental features which could be indicative of (dis-)comfort, anxiety, ease, and the like;

- The language used in the interview was Spanish in order to eradicate any possible linguistic barriers that could obscure the meanings sought with the interview.

\subsection{Data analysis}

The interviews were conducted following the recommendations provided in the relevant literature, e.g. (i) requesting informed consent to the respondents, (ii) piloting and grading the questions beginning by non-threatening ones with a view to establishing rapport (e.g. what year are you in? Are your family happy about you studying to become an English teacher? Did you learn English before getting into university?) And later smoothly moving to questions intended to elicit the respondent's views, opinions and knowledge about the phenomena at hand; (iii) recording and transcribing the interview orthographically -with some occasional use of phonetic diacritics where key meanings had to be faithfully represented (e.g. use of marking for tones and pauses in the main); (iv) analysis of the data following rigorous iteration procedures of content analysis (e.g. memoing). The whole process of 
administering the interviews, transcribing them and analysing them took approximately six weeks.

As for the data analysis process proper, I must point out the following:

- Because of the linguistic nature of the data collected, I transcribed it following some basic conventions of phonemic transcriptions, viz. division of text into intonation groups, identification of nuclear accents in potentially rich utterances, and occasional marking of tones in particular utterances;

- Halfway through the transcription the researcher noticed a high degree of iteration, yet the whole data was eventually transcribed;

- After the whole material was transcribed, the transcription was read with a view to looking for patterns, some of which had become apparent during the transcription phase;

- Content analysis: The patterns found were annotated on the margin using labels that corresponded to the core elements contained in the research questions (memoing);

- Finally, a last reading of the transcription -and memos in particularwas carried out with the purpose of clustering patterns together, thus establishing categories for later analysis.

\subsection{Sampling}

As for sampling, the size of the respondent sample does not necessarily follow the same pathway as in quantitative studies, where individual differences must be 'ironed out', as Dörnyei (2006: 126) puts it. This does not mean that -because of the nature of the study, where respondents' individual experience makes the crux of the phenomenon- a study of this type presents no sampling parameters. In this study, a purposive sample has been employed; it is fairly homogeneous in that all respondents are pre-service English teachers who have taken at least one phonetics/pronunciation course at a Chilean teacher-training college. Within the sample, the researcher has applied selection criteria traditionally associated with quantitative studies: The sample corresponds to a random stratified one in that respondents have been selected on a random basis and belong to different groups or 'strata' (years in their curriculum progression). 


\subsection{Research questions and objectives of the investigation}

The research aim of this investigation is to ascertain and increase the level of awareness of complex constructs such as Englishes, foreign accent vs. native accent, and native speaker within a framework of an everchanging socio-political structure, in a sample of pre-service teachers of English from the periphery (Chile); yet the operationalisation of this macro-aim, results in more concrete research questions, as Cohen and Manion (2007) argue.

As pointed out earlier in 1.0, this study is immersed in the CALx approach, where a qualitative methodology has been used, thus the research questions set forth in this study reflect the nature of the investigation itself in that, as Dörnyei (2006) claims, they are 'broader than quantitative ones, often focusing on the big picture or the main processes that are thought to shape the target phenomenon', (p. 74).

As Grix (2004) suggests, both the methodological approach and methods are closely intertwined with the research questions and, in turn, the ontology and epistemology that underpin them. Consequently, this piece of research is not driven by method, but by the nature of the research questions below:

- What accent(s) are resampled pre-service teachers of English exposed to and encouraged to learn (by their lectures)? Why?

- What are the pre-service teachers' perceptions and beliefs about having lecturers and schoolteachers with a native accent or a foreign accent?

- To what extent are pre-service teachers of English aware of the spread of English?

- (How) Have lecturers and the course structure contributed to the construction of the belief systems held by pre-service teachers with regard to native accent and foreign accent?

\subsection{Validity and reliability}

As for validity, traditionally understood as whether an instrument measures what it purports to measure (Cohen and Manion, 2007), the researcher has followed a series of procedures intended to ensure valid results and conclusions. It must be pointed out that in the case of interviews; validity is primarily based upon whether the questions asked 
measure what they claim to measure and bias-minimisation. These are some of the initiatives adopted to safeguard validity:

a. The accounts have been interpreted safeguarding their original wording;

b. The interviewer, a senior pre-service teacher, was properly trained for this particular task (an assistant was required since the researcher happens to be one of the phonetics lecturers and the Head of the programme, which posed a potential for bias);

c. The interviewer is held in pre-service teachers' high esteem and evinces minimum power relations;

d. Because of the status of the interviewer, the level of acquiescence is minimised;

e. The results prove to explain the phenomena at hand.

Reliability is usually understood as consistency and replicability over time, over instruments and over respondents, particularly in quantitative studies, (Cohen and Manion, 2007); in qualitative investigations, however, it is sometimes argued that due to the uniqueness of the contexts researched replicability is virtually unattainable. Nevertheless, reliability can also be dealt with by ensuring, during the analysis phase, that the observations remain the same even if they are made at a different time or a different place, and most importantly, incorporating an element of inter-rater reliability in the form, as is the case of the present investigation, of consultation with a colleague for impressions on the analysis of the results.

\subsection{Findings}

In order to probe into the respondents' perceptions related to accent, a series of questions were put to them, all of which addressed the construct from various angles, namely (i) accent(s) learned or exposed to at university, together with the reasons for the choice(s); (ii) accent(s) that lecturers and schoolteachers should have; (iii) extent of awareness of the spread of English and its current status in the world; and (iv) lecturers' influence on the belief systems of the respondents. As can be observed, the questions put to the respondents fall into four themes that correspond to the four research questions of this investigation. Thus, the analysis is structured around such four themes. 


\subsection{Exposure to accent(s) at university and reasons for choice}

When asked what accent(s) of English they have learned, all of respondents mentioned British English (BrE henceforth; RP and BrE are most often used interchangeably), especially in the phonetics courses; four of the respondents pointed out that they have also learned American English (AmE for short), because other lecturers speak it -not because it is taught systematically. It is interesting to observe that three respondents offered value judgments attached to BrE: one of them remarked -as a pseudo-justification for the teaching of it- that ' $\mathrm{BrE}$ is more formal, more correct and has less slang'; another respondent views BrE as a 'more beautiful and formal accent'. Another respondent, unveiling a degree of exasperation by means of prosodic features, pointed out that 'the university imposes RP on the students'.

The answers offered to the question relating to the exposure to accent(s) during the course of studies do not differ from those presented above; only one respondent stated the reverse, i.e. the accent he had been exposed to was AmE in the main, yet 'BrE gives you more prestige'. It is interesting to observe that all those who mentioned both accents as learned or exposed to present $\mathrm{BrE}$ and $\mathrm{AmE}$ in that order, which surely reveals the different levels of emphasis. BrE equally prevails in responses to the question relating to accent(s) they are encouraged to learn as preservice teachers, although four respondents unequivocally stated they there was no imposition. Interestingly, one of them expressed a degree of imposition indirectly 'exerted by their fellow students'. Yet again, four responded that $\mathrm{BrE}$ 'is a more beautiful and pleasant accent and easier to understand'; 'it is more elegant, formal, and precise', while 'AmE is kind of more informal'. Without doubt, the statement that reveals a rather worrying misconception is one that stated that ' $\mathrm{RP}$ is to be used by intelligent people alone'.

The above reveals that the teaching of English at this particular teacher education institution follows 'inner circle' models, following Kachru's (1986) scheme, and approximates more closely Quirk's recommendation of not exposing students to a great variety of 'English usage'.

The teaching of BrE or AmE as socially prestigious varieties seems to consolidate radical recommendations, as those made by Quirk (1985) of sticking to 'standard varieties' of English; similarly, it perpetuates inequality and foregrounds power relations of dominant countries. Thus, dominant varieties of English enjoy tenure of exceedingly positive labels 
(Philipson, 2003), while other varieties of English are barely known by the respondents.

As for the reasons given by their lecturers as to why a particular accent is used as a model accent (RP in this case), a third of the respondents told the interviewer that they could not fully remember the reasons, yet they ventured possible explanations: 'I don't quite remember, but I presume it's because it's the most important'; 'I don't actually remember, but perhaps because RP is more formal than GA, more standard'; 'it's more standard and offers better job prospects'. Three respondents remarked that they had not been given any explanations at all and equally offered their own conjectures: 'I have never been told why, but my guess is that it is because it the mother accent'; 'I think it is because it is a wellrespected accent; it's more formal'. The remaining handful reported on what they had seemingly been told by their corresponding lecturers and stated that 'it is because AmE is of a lower level'; '[RP] it's easier to understand and it's more neutral'; '[RP] it's more formal and it's got less slang than AmE; it's easier to understand across the world'.

\subsection{Lecturers and schoolteachers with a native or a foreign accent}

The responses do not vary greatly when asked about the accent that schoolteachers should have from those mentioned in 4.1: half of them pointed out that teachers should speak RP because 'it is purer', 'more elegant and beautiful', and because 'it is like the mother accent'; 'it is more academic, more understandable, and more globalised'. The same condition applies to the accent that university lecturers should have. These notions certainly collide head-on with some investigation conducted on, for instance, the degree of comprehensibility of RP.

The remaining half is equally divided into those who believe that 'teachers should use one accent in particular and avoid mixtures' and those who believe that schoolteachers should speak various accents.

Only four respondents believe in-service teachers should speak English with a native accent, claiming that exhibiting a native accent 'is desirable because they serve as models for the students'. Another three respondents agree that pre-service teachers should aspire to a native accent, yet they admit that it is rather difficult to achieve such performance, whilst six respondents played it down on exhibiting a native accent, laying more emphasis on the importance to speak the language the best way possible and the mastery of pedagogical skills to teach it. 
As can be seen, the positive concepts that speaking RP enjoys do not go hand in hand with reality: the actual population of RP speakers continues to dwindle and not more than $2 \%$ or $3 \%$ speak it in the British Isles, as reported by Crystal (1997), yet traditional views of accent seem to prevail. This might be the case because, as Jenkins (1998) points out, there is still scant research on English used in non-native contexts. A paradigmatic change in this respect is certainly no easy task and will only be possible when 'we have adequate descriptions of EIL varieties', (Jenkins, 2006: 61).

On a slightly different level, nearly all the respondents pass very harsh judgments on people who exhibit a 'Chilean accent' in English. They were asked about the implications of such a situation and some of the most frequent scenarios is that of teaching, in which case respondents seem to project higher expectations from teachers where they are not only speakers of a foreign language, but teachers (models) of that language. The responses appear less harsh on those who are not teachers of the language, yet in most cases they see a Chilean accent as a factor that might undermine the person's potential in the job market or simply when travelling.

As for the actual contact the respondents report they have with native speakers of English, the respondents admitted that they, by and large, rarely speak English with native speakers outside the university where they do speak 'with Becky (the British language assistant) twice or three times a week'. Only a handful of respondents manage to practise the language with relatives based in English-speaking countries or even with 'passing mormons'. The vast majority of them, 10 out of 15 , pin hopes on travelling overseas, thus suggesting that in that manner they will be able to communicate with native speakers and ultimately improve upon their English/accent.

The above is exactly the type of scenario that should make teacher trainers revisit some of their teaching practices. As Jenkins (2000) warns, we continue to teach English as though our students were bound to engage in communication with native speakers in the main.

\subsection{Extent of awareness of the status of English in the world and the spread of English}

The knowledge evidenced by the interviewees about the existing varieties (not only accents) of English seems rather meagre; most of them acknowledged the existence of many and one them even dared say that 
there are 'thousands', while those who ventured a figure placed it on a scale of three to six. As for the countries where English is spoken as an official language, 12 of the respondents mentioned three or four countries at least, amongst which are England (or The UK), The US, Canada, and Australia. Interestingly, three students wrongly mentioned countries such as Mexico (two mentions), Togo and Sweden, while only three respondents included different countries from the aforementioned such as New Zealand, Jamaica and Ireland. Two respondents observed that 'in Africa they also speak English'.

When probing into the respondents' more restricted -though presumably more familiar- knowledge, about the countries where English is spoken as an official language in the Americas, the results do not differ greatly from those shown above: 13 respondents mentioned The US and Canada; only five respondents correctly included countries other than those mentioned above such as Bahamas, Guyana, Puerto Rico (not a sovereign state), and Jamaica. Interestingly, there were six wrong mentions of countries where English is spoken as an official language: Alaska (not a country), Mexico (three mentions), and Cuba (two mentions). The responses do not vary greatly when it comes to the varieties of English the respondents have heard, which comprise those spoken in The US, Australia, Canada, and England, in the main. In a slightly similar vein, the respondents showed a keen interest when asked about whether pre-service teachers of English should be exposed to diverse varieties of English. All of them believe they should be exposed to different varieties of English and offered different reasons where the value of multicultural understanding was underscored. One of them remarked: 'of course we should be exposed to other varieties of English; it's really important for better communication'; another respondent observed that 'it's crucial to become aware of the existing diversity; it's part of acquainting yourself with a culture'.

Yet again, the narrow perspectives that respondents evidence with regard to an ongoing change in the status of English in the world seems to respond to fossilised views contained in teaching materials, which take the form of (somewhat hidden) discourses that lectures also come to believe in, according to which there is a hierarchy of accents.

\subsection{Lecturers' influence on pre-service teachers' belief systems}

The fact that mentions of RP -or BrE, for that matter- greatly outnumber mentions of AmE is partly due to fact that, as pointed out by the 
respondents, the materials used in pronunciation practice, especially in their phonetics courses feature RP alone. The scarce allusions to AmE as used in their teaching materials were connected to the English language courses.

The power exerted by the discourse, both explicit and hidden, used by the lecturers comes across as quite strong. Although the respondents do not openly attribute the reasons why RP has been the preferred accent to be learned to their lecturers, they seem to go back to their first pronunciation lessons to retrieve what they heard from them in order to venture responses. Indeed, the degree of homogeneity amongst the responses cannot possibly result from haphazardness. Such discourses are further complimented throughout the programme with the use of pronunciation materials that, for the most part, feature RP alone. Such a combination appears to be the main source of the creation of value systems attached to accents, RP and GA in the main.

The values that the respondents express with regard to accents, presumably inherited from their lectures and the structure of their courses and materials, best represent one extreme of a continuum which has largely prevailed in the expanding circle and, perhaps to a lesser extent, in the outer circle: nativeness. Such pursuit can well prove rather disappointing, especially if we take the evidence from psycholinguistics seriously in relation to accent attainment in post-puberty language learners, which is the case of Chile (see Scovel, 1988).

\subsection{Final remarks}

It is interesting to note that for more than seven decades now, worldrenowned linguists such as Abercrombie (1949) have hinted that teaching should focus on achieving intelligible pronunciation, at the expense of a native accent. Certainly, a distinction must be made based upon the language use(s) that the learner pursues, i.e. the degrees of linguistic depth greatly vary between a businessman language learner and a prospective teacher of English as a language learner. However, an element of truth in Abercrombie's call applies to both.

If English language teaching is to shift away from the 'nativeness' principle to a more 'intelligibility' perspective, further ground needs to be broken in, as Derwing and Munro suggest (2005), the area of the possible relationships between accent and pronunciation teaching; the various contexts of communication, (Levis, 1999); adequate descrip- 
tions of EIL, (Jenkins, 2006), amongst other aspects. Similarly, further investigation is required in all the sub-senses of what is at times loosely termed intelligibility. In this respect, Smith and Nelson (1985) have provided an interesting theoretical framework, which needs to be further studied and empirically underpinned. Thus, the present investigation and its conclusions only contribute to pushing such pursuits even more strongly.

\subsection{Conclusions}

This small-scale investigation sheds light on the research questions set forth in section 4 and the most evident conclusions (together with calls for change) are presented below:

(i) Pre-service teachers of English claim that the accent they have learned (or have been encouraged to learn) and heard is RP and, to a much lesser extent GA.

(ii) The respondents exhibit highly stereotypical representations of the accents, particularly of RP; they wrongly associate a higher level of formality, elegance, comprehensibility, ease, correctness, and purity with RP. GA, on the other hand, comes across as a rather informal accent and of a lower level.

(iii) Seemingly, on account of the same depictions of RP, respondents believe that teachers should speak that accent or, to a lesser extent, one accent in particular (either RP or GA).

(iv) Much of the wrong perception of accents is largely passed on the students by their own phonetics lecturers in ways that are not explored in depth in this study, which calls for immediate action. Also, the construction of the belief system associated with RP seems to be affected by the use of pronunciation materials that, by and large, use RP as the model accent.

(v) The respondents' misconceptions seem to partly stem from the fact that the knowledge they have about the existing varieties (not only accents) of English is rather meagre. While most of them acknowledge the existence of many English varieties, the respondents were only able to mention four on average. The same degree of limited knowledge applies to countries where English is spoken as an official 
language, both at a global and regional level. Broadening up in-service teachers' horizons of the on-going spread of English, presence of the English varieties in the world, from an unbiased stance can certainly contribute to less judgemental comments, beliefs and attitudes about accents. This can be achieved in various ways, viz. a workshop on world Englishes and the spread of English intended for teacher trainers, the dissemination of the results of the present investigation amongst phonetics lecturers, the incorporation of a module into relevant courses of the curriculum dealing with the issues treated herein, the organisation of a seminar on world Englishes, amongst others.

(vi) Notwithstanding the respondents' split views as to whether teachers should speak English with a native accent, where nearly half of them lay more emphasis on intelligibility at the expense of accuracy, the respondents pass very harsh judgments on individuals who exhibit a 'Chilean accent' in English. It appears that respondents project higher expectations from teachers where they are not only conceived as speakers of a foreign language, but models of that language. Consequently, the responses appear less harsh on those who are not teachers of the language, yet in most cases they see a Chilean accent as a factor that might undermine the person's potential in the job market or simply when travelling.

The above suggests that pre-service teachers of English may not eventually speak with a native accent, despite the emphasis given to pronunciation accuracy in their courses, yet they to wish to avoid a Chilean accent as prospective teachers of English, partly due to the impact it can have on their job prospects and the potential loss of credibility attached to exhibiting a Chilean accent.

(viii) From the above it becomes apparent that pre-service teachers of English should become acquainted with the phonological core proposed by Jenkins (ibid.), particularly because the prospective students of our teacher trainees are most likely to use English as an international language. 


\section{References}

Abercrombie, D. (1949). Teaching pronunciation. English Language Teaching, 3, 113-122.

Breitkreutz, J., Derwing, T., Rossiter, M. J. (2001). Pronunciation Teaching Practices in Canada. TESL Canada, 19, (1), 51-61.

Cohen, L., \& Manion, L. (2007). Research methods in education. (6th ed.) London: Routledge.

Cresswell, J. (2003). Research design: Qualitative, quantitative, and mixed methods approaches. Thousand Oaks, CA: Sage Publications.

Crystal, D. (1997). English as a global language. Cambridge: Cambridge University Press.

Derwing, T. and Munro, M. (2005). Second language accent and pronunciation teaching: A research based approach. TESOL Quarterly, 39, (3), 379-397.

Deterding, D. (2005). Listening to Estuary English in Singapore. TESOL Quarterly, 39, (3), 425-440.

Dörnyei, Z. (2006). Research methods in applied linguistics: Quantitative, qualitative, and mixed methodologies. Oxford: Oxford University Press.

Fairclough, N. (1992). Discourse and social change. Cambridge: Polity Press.

Ferguson, G. (2006). Language planning and education. Edinburgh: Edinburgh University Press.

Gass, S. and Varonis, E. M. (1984). The effect of familiarity on the comprehensibility of non-native speech. Language Learning, 34, 65-89.

Grix, J. (2004). The building blocks of research. London: Palgrave Macmillan.

Halliday, M.A.K. (1964). Comparison and translation. In M.A.K. Halliday, M.McIntosh and P. Strevens, The linguistic sciences and language teaching. London: Longman.

Hedge, T. (2000). Teaching and learning in the language classroom. Oxford: Oxford University Press.

Jenkins, J. (1998). Which pronunciation norms and models for English as an International Language? ELT Journal, 52, 119-126. 
(2000). The phonology of English as an international language. Oxford: Oxford University Press.

(2002). A sociolinguistically based, empirically-researched pronunciation syllabus for English as an international language. Applied Linguistics, 23, 83-103.

(2006). The times they are (very slowly) a- changin'. ELT Journal, $60,1$.

Kachru, B. (1986). The Alchemy of English: The spread, functions and models of non-native English. Oxford: Pergamon.

Levis, J. (1999). Intonation in theory and in practice, revisited. TESOL Quarterly, 33, 37-54.

(2005). Changing contexts and shifting paradigms in pronunciation teaching. TESOL Quarterly, 39, (3), 369-377.

(2006). Pronunciation and the assessment of spoken language. In Hughes, R. (ed.). Spoken English, applied linguistics, and TESOL: Challenges for theory and practice, 245270. Palgrave Macmillan.

Lightbown, P. and Spada, N. (1999). How languages are learned. Oxford: Oxford University Press.

Lippi-Green, R. (1997). English with an accent: Language ideology and discrimination in the United States. New York: Routledge.

Long, M. (1990). Maturational constraints on language development. Studies in Second Language Acquisition, 12, 251-285.

MacDonald, S. (2002). Pronunciation -views and practices of reluctant teachers. Prospect, 17, (3), 3-18.

Munro, M. and Derwing, T. (1999). Foreign accent, comprehensibility, and intelligibility in the speech of second language learners. Language Learning, 49, 285-310.

Nunan, D. (1999). Second language teaching and learning. Boston: Heinle \& Heinle.

Ogden, C. (1939). Basic English. In Ferguson, G. (2006). Language planning and education. Edinburgh: Edinburgh University Press.

Pennycook, A. (1999). Critical applied linguistics: A critical introduction. Mahwah, NJ: Lawrence Erlbaum. 
Phillipson, R. (2003). English-Only Europe? Challenging language policy. London: Routledge.

Prator, C. (1968). The British heresy in TESL. In Fishman, J. C. Ferguson $\&$ J. Das Gupta (eds). Language problems of developing nations. New York: John Wiley, 459-476. In Furguson, G. Language planning and education. Edinburgh: Edinburgh University Press.

Quirk, R. (1985). The English language in a global context. In Quirk, R. and Widdowson, H. (eds.). English in the world: Teaching and learning of language and literature. Cambridge: Cambridge University Press.

(1981). Nuclear English. In Smith, L. (ed.). English for cross-cultural communication. London: Macmillan.

(1989). Language varieties and standard language. English Today, 21, 3-10.

Scovel, T. (1988). A time to speak. A psycholinguistic inquiry into the critical period for human speech. Rowley, MA: Newbury House.

Seidlhofer, B. (2003). Controversies in applied linguistics. Oxford: Oxford University Press.

Smith, L. and Nelson, C. (1985). International intelligibility of English: Directions and resources. World Englishes, 4, (3), 333-342.

Stuparyk, M. (1996). New Canadians eager to master English: Course helps Canadienze accents. In Derwing, T. and Munro, M. Second language accent and pronunciation teaching: A research based approach. TESOL Quarterly, 39, (3), 379-397.

Usher, J. (1995). Teaching pronunciation: Inhalation/exhalation helps students distinguish sounds. In Derwing, T. and Munro, M. Second language accent and pronunciation teaching: A research based approach. TESOL Quarterly, 39, (3), 379-397.

Willis, J. (1996). A framework for task-based learning. Harlow: Longman. 